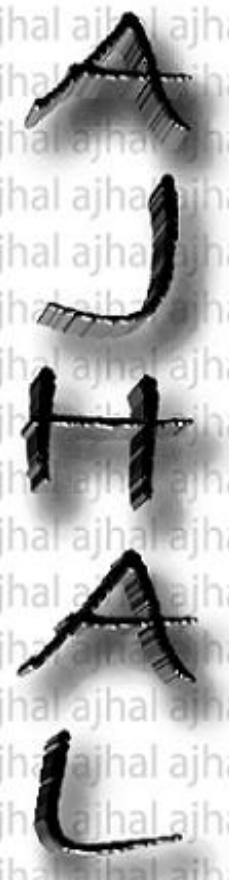

[SSN 2314-8636

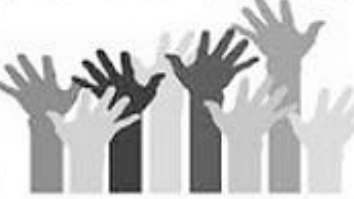

THERET5ாם 토月P工田

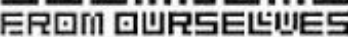
잩 HШாПП 코느ㅌㅣㅐㅛ

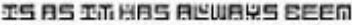
月กㅋ 트 5ㅁㄴㅃㅌㅡ

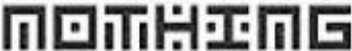

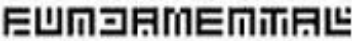

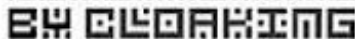
口URSE느트

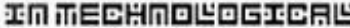
Б늠ㅁㅍㅜ Vol 3, No. 1/2016

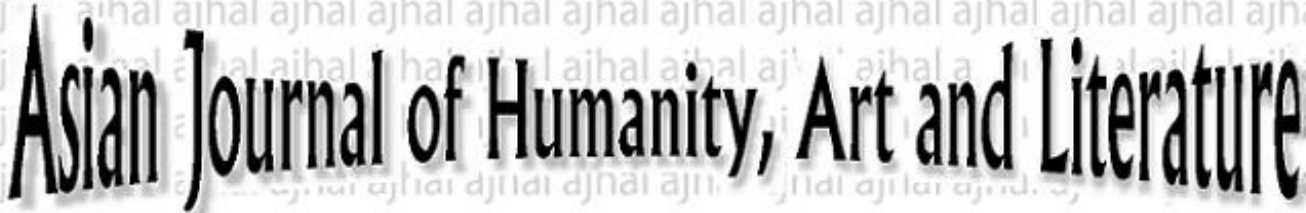




\section{An Overview of the Heritage of Kalicharan Shaha Street: Approach to the Area Conservation}

ISSN: 2311-8636 (Print) ISSN: 2312-2021 (Online)

DOI prefix: 10.18034/ajhal

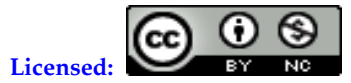

Source of Support: Nil

Conflict of Interest: None Declared

*Email for correspondence: intisarameen@gmail.com

\section{Saniya Tabassum, Intisar Ameen Tyne*}

Department of Architecture, Stamford University Bangladesh, House no-19/A, Road-6 Dhanmondi R/A, Dhaka-1205, BANGLADESH

\section{ABSTRACT}

Dhaka is a successor of a rich cultural inheritance of 400 years. Dhaka's glorious history passed through many phases of architectural development, keeps some traces of almost all types of progression. But it continued to survive by making remarkable adjustments with the new challenges. With the assuming political and economic dynamics, rapid urbanization, uncontrolled development and lack of awareness, these heritages of historic Dhaka are destroying day by day. Beside the mighty river of Buriganga initiates such an old neighborhood just around the 550 feet Long Street named Kalicharan Shaha Street, reflecting the organic settlement pattern started to develop during the Mughal and Colonial era. The study has outlined the direction to provide some data, information and documentation of the neighborhood along Kalicharan Shaha Street to identify historical, cultural and planning aspects of that episode. It is an approach to show how the indigenous culture was blended with the colonial one and reflection of it over the forms and features of the neighborhood. Therefore it deals with some key aspects of built form, facade treatment and ornamentation, occidental and oriental relationship of the buildings, and along with the spatial order of morphological change, as the cultural heritage element for conserving this area. Thus, this paper is an approach to emphasize the heritage of Kalicharan Shaha Street in a public eye, so as to make people aware of the conservation of the heritage of our city.

Key Words: Kalicharan Shaha Street, heritage, settlement pattern, built form, conservation

\section{INTRODUCTION}

Though Dhaka (originally Dacca) as a district is a British creation, the history of the city of Dacca goes back to the early Mughal period. Established as the capital of Bengal in 1610 [Karim, 1964], the city continued to retain its glorious status for the next four centuries. During this time due to social and political change, Dhaka has been portrayed as a continual urban existence with its ups and downs [Islam,2011].Therefore, it acquired a new dimension in urbanization and architecture. The uniqueness of its settlement pattern appears from a resemblance of a chain of the stylistic experiment in a blend of eastern and western architecture with some traditional features of Bengal which produced an extraordinary heritage.

Beside the mighty river of Buriganga lays such a neighborhood, just around the 550 feet long street named Kalicharan Shaha Street. The settlement of this area started to develop 
during the Mughal era. During the British reign due to changing dynamics of politics and trading, a different craftsmanship [residence for the workers of sugar mill], established in that area and retained the character of indigenous settlement pattern, spatial hierarchy and social bondage. But after liberation these qualities with heritage values are under threat. Reckless destruction of heritage and intervention by people and building new as part of development has precedents. Thus this paper is an approach to emphasize the heritage of Kalicharan Shaha Street in public eye, so as to make people aware of the conservation of heritage of our city. And also aspires to make the inhabitants cautious of their assets, so that they can make an effort to maintain the previous characteristics. From the field survey, it seems to be urgent that this area with some particular buildings that still embrace with their unique grandeur should be conserved soon before it lost its original outstanding features.

\section{The context}

The 10'-12'wide Kalichara Shaha Street started from the K.B road at south and struck beside the road at Dholai Khal at north-west side. At the south-west of the street, the mill barrack with a huge field has a high impact to develop this vibrant community. The society of this area has its own identity and an enormous bonding with its surroundings like neighborhood of Forashgonj at North [Fig 1]

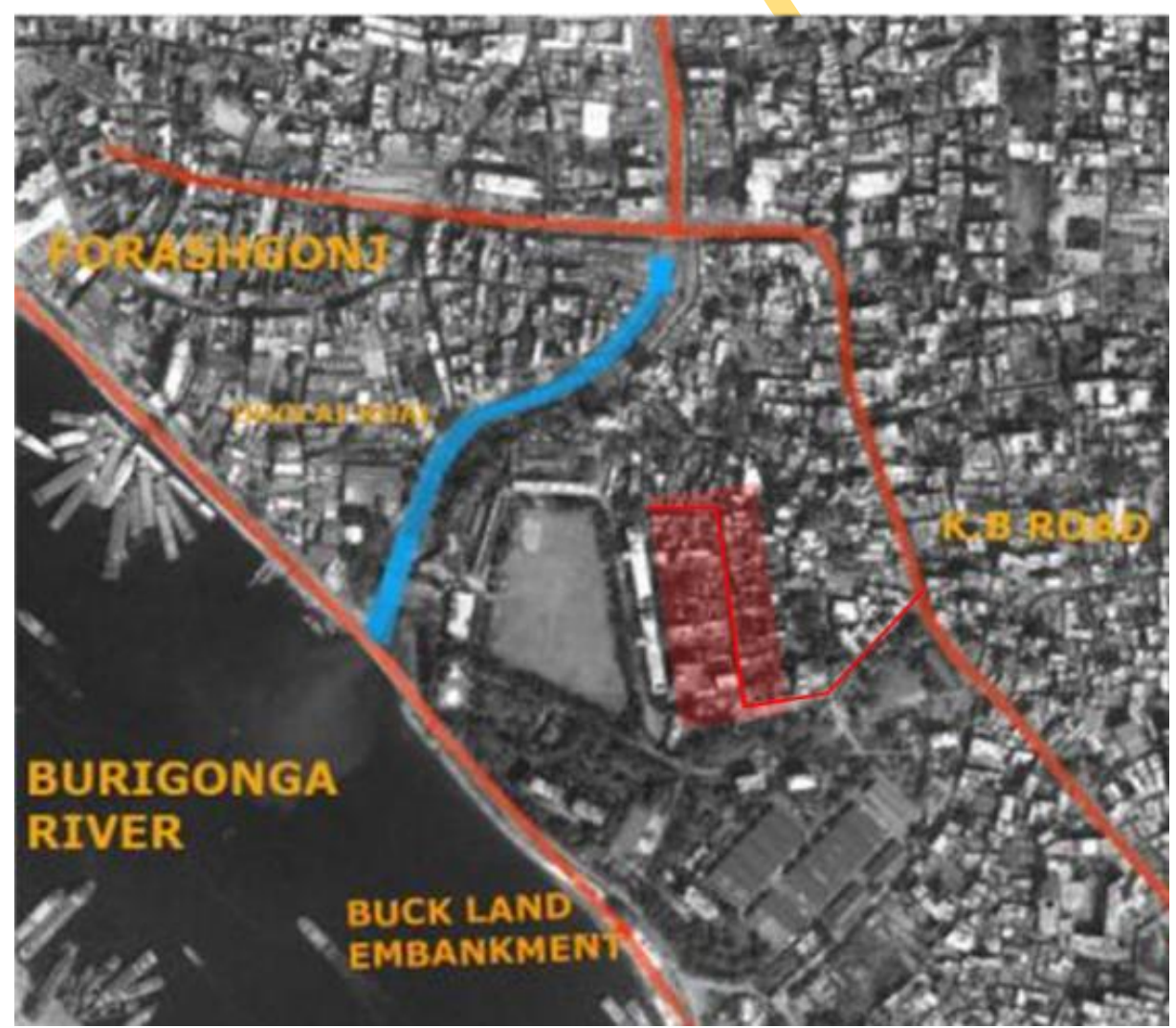

Figure1: Location of the Study Area 


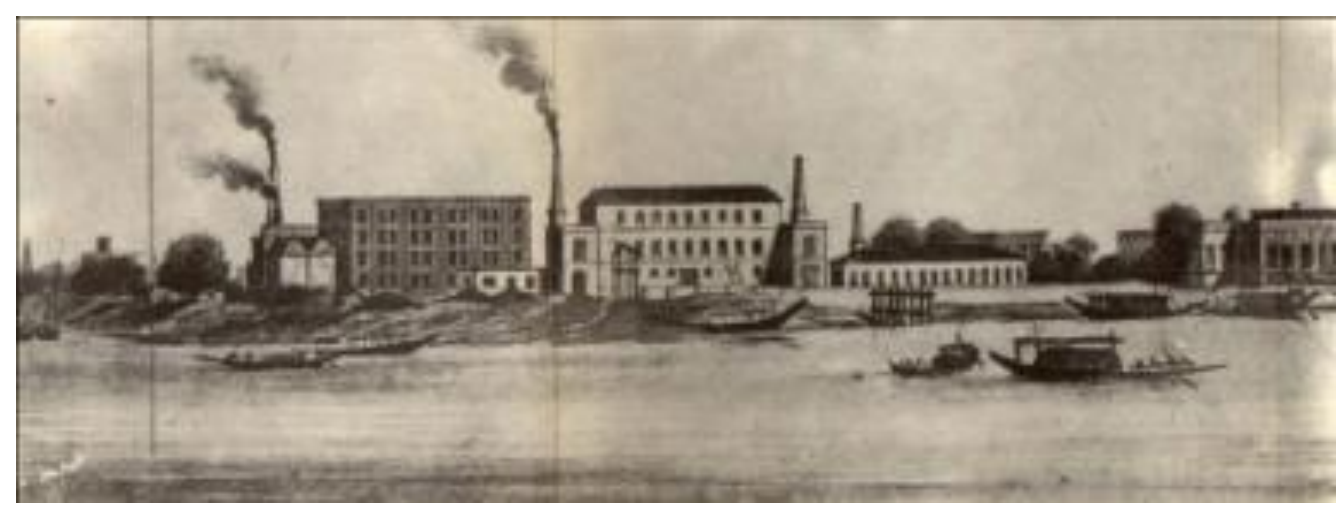

Figure 2: View of Buriganga and Sugarmill beside Kalicharan Shaha Street [Mamun.1993]

\section{Historical Background}

Around 1840, an anonymous artist painted a building named "Dhaka Sugar Works Company" which was located beside the Buriganga River [Fig 2] [Mamoon, 1993].There were some buildings that are now known as Millbarrack. The trace of the sugar mill can be found until 1850. The newspaper of respective time named "Dhaka News" shows the indication of a flour mill in this particular area at 1858. One British man named "William Foley" placed the Flour Mill after the closing of that sugar mill due to severe financial loss. According to his name the mill was known as the "Foley's Mill". During the 'Sipahi Mutiny' of 1857-1859 (first freedom movement of the subcontinent) British troops brought from Calcutta to quell the mutineers at Dhaka. Many of the mutineers of Fort were detained here for the trial. Since that time, this building and its surrounding area became known as Mill Barrack. In 1867, the government announced that the mill and its surrounding area will be a Cantonment. Between 1903 to 1912 a police training school and sub-inspector cadets were established [Mamoon, 1993].

The history and change of mill barrack area had a high influence to develop a vibrant

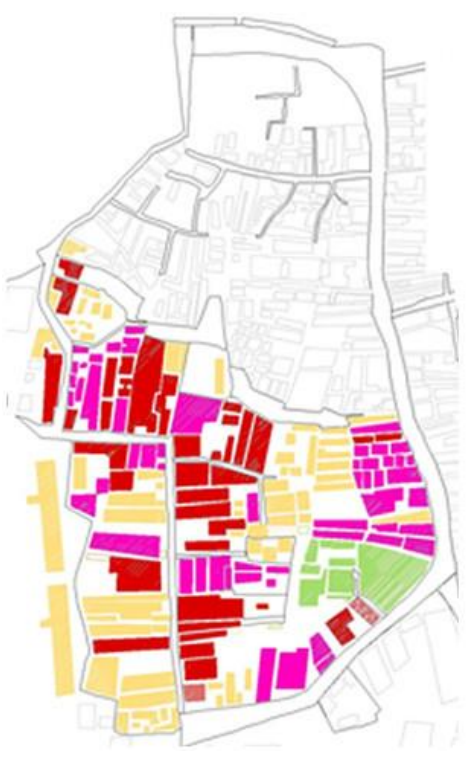

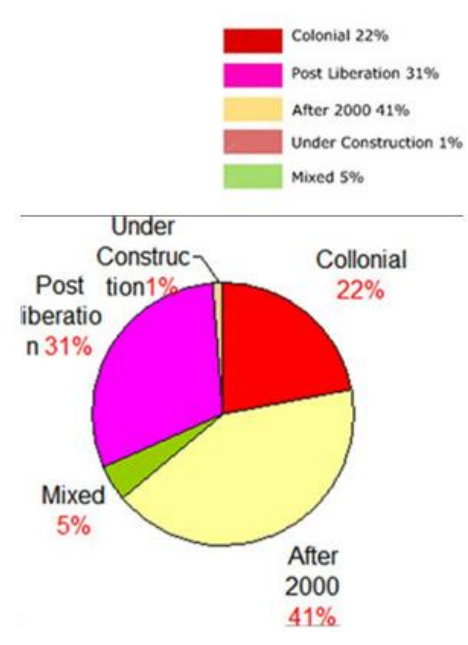
neighborhood around the kalicharan Shaha Street. From the local community, it has been heard this street was named after kalicharan Shaha, a social worker of that period. Among the houses of the total community $22 \%$ were built during the colonial era, $31 \%$ after the liberation war [fig 3].

Figure 3: Building Fabric of Kalicharan Shaha Street 
As being an age-old neighborhood and due to the lack of proper maintenance most of the structures are in a deplorable condition. In the meantime $41 \%$ house has changed their original fabric by the year 2000, $5 \%$ of these buildings turned into shops at the bottom level. Therefore, the unique heritage of this area is degrading day by day and becoming a degenerated amalgamation of various new developments.

\section{The Heritage of Kalicharan Shaha Street}

\section{Settlement Pattern}

The neighborhood of Kalicharan Shaha Street used to be considered as one of the old neighborhoods of Dhaka city. From Colonial period, Kalicharan Shaha Street was the place of Hindu traders and mill workers. The religion and the profession had a subterranean impact on the physical character of this settlement. The urban fabric of this area has a strong spatial quality of indigenous character. At present, the dense condition shows a dilapidated image of the organic pattern with closely spaced buildings. The settlement developed from a central axial spine of communication that is the road, and the plots were arranged along the road. The road is very narrow (10-12 ft) and intimate in nature and acts as the main spinal road holding a vibrant community [Fig 4].

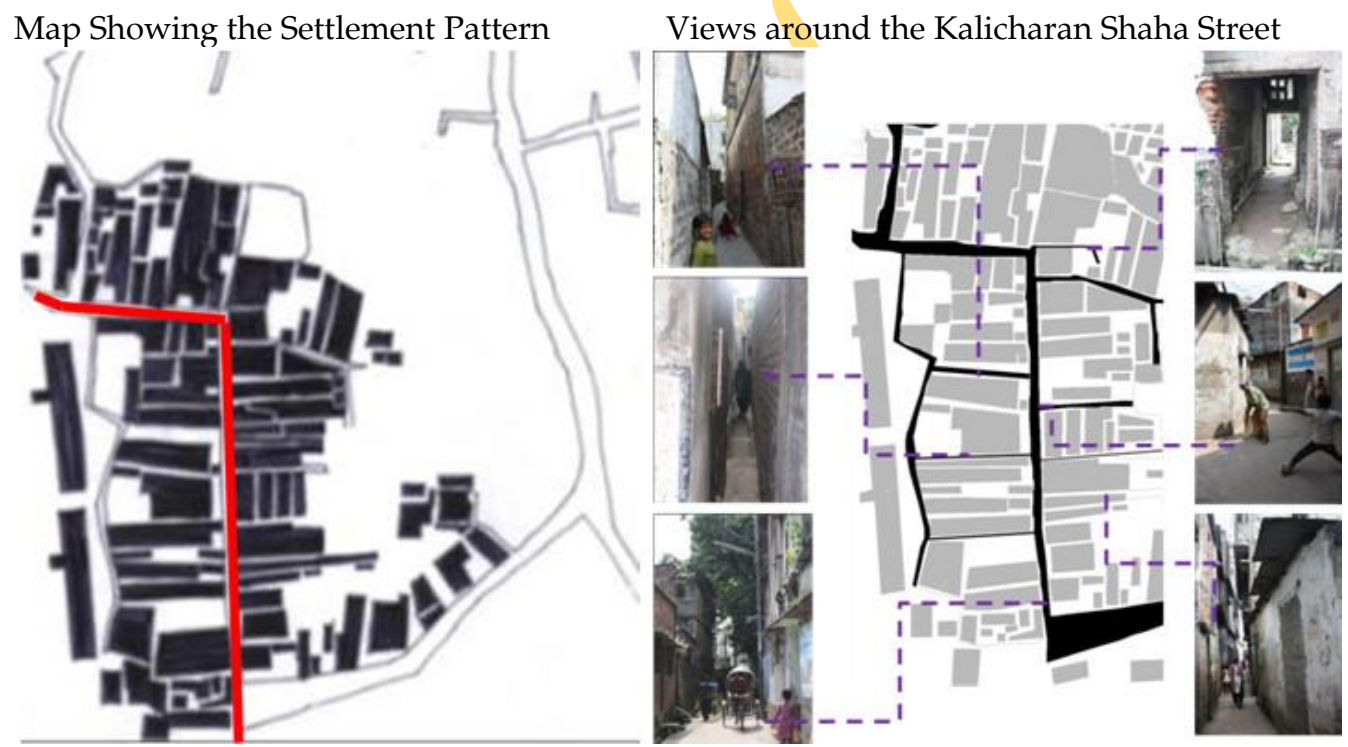

Figure 04: Settlement Pattern of Kalicharan Shaha Street

Socio-cultural dynamics in this area resulted in the formation of a spontaneous neighborhood, known as para mahalla, which acts as the basic spatial unit of the organic pattern in the urban web (Mowla, 1997). It is observed that the formation of major Kalicharan Shaha Street is typically accompanied by municipal services. The settlement developed through a hierarchy of spaces and hierarchy of social relationship: courtyards, narrow lanes, nodes, and bazaars that manifested the socio-cultural quality of urban life ( Mowla, 1997).

Most of the internal streets [narrow lanes or galis] are dead end with 3-4 ft road act as the neighborhood meeting place [fig 4,5]. Mill barrack field and the bank of Dholai Khal act as the community open space for children and young [fig 6]. Beside this, irregular pattern of 
open space [courtyard] exist in front or central or back side of almost every house. Most of these open spaces are used by the family as private space [cooking, washing etc.] or sometimes areas of intimate contact with their neighbors [fig 7]. Among the total buildings of the area $83 \%$ are residential, $2 \%$ small scale commercial, $2 \%$ religious, $1 \%$ cultural facilities and $11 \%$ mix used structure.

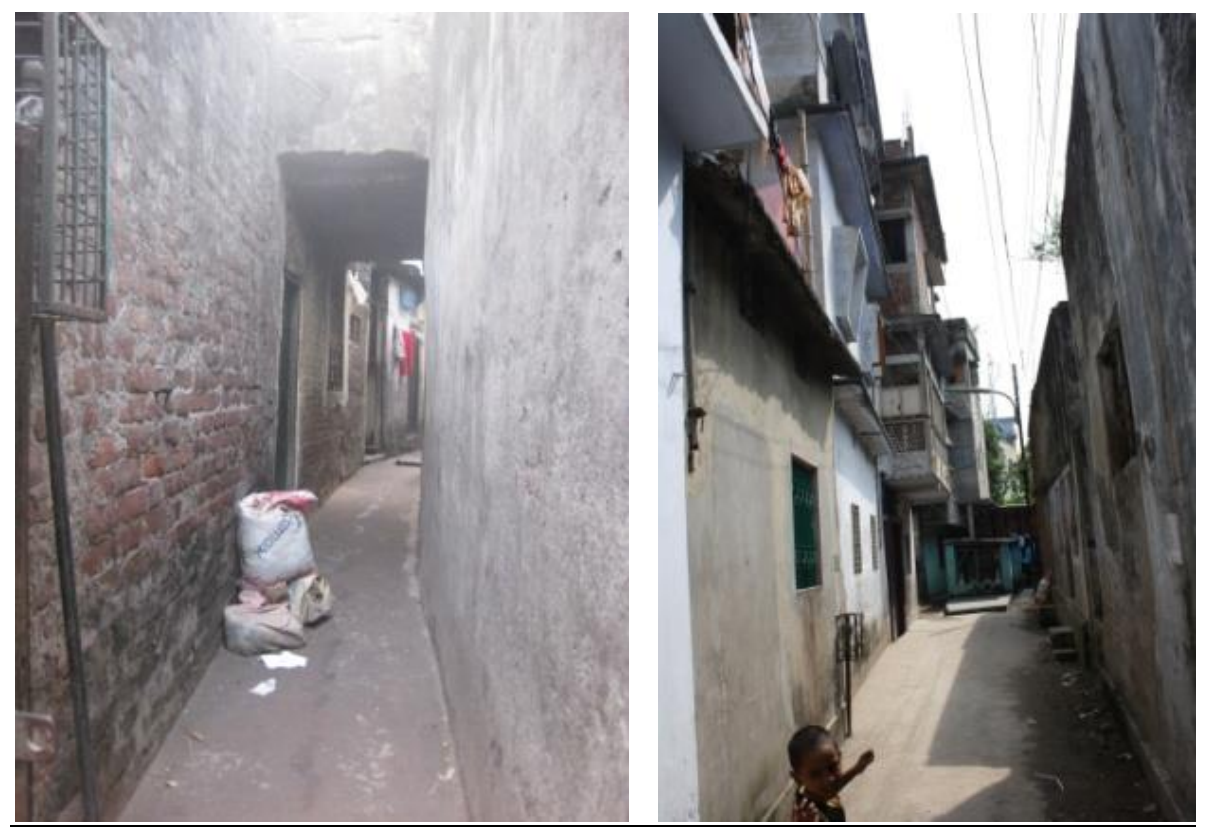

Figure 5: Narrow Lanes and Dead Ends

Space in Mill Barrack

Mill Barrack

Bazar|at the Bank of Dholai Khal
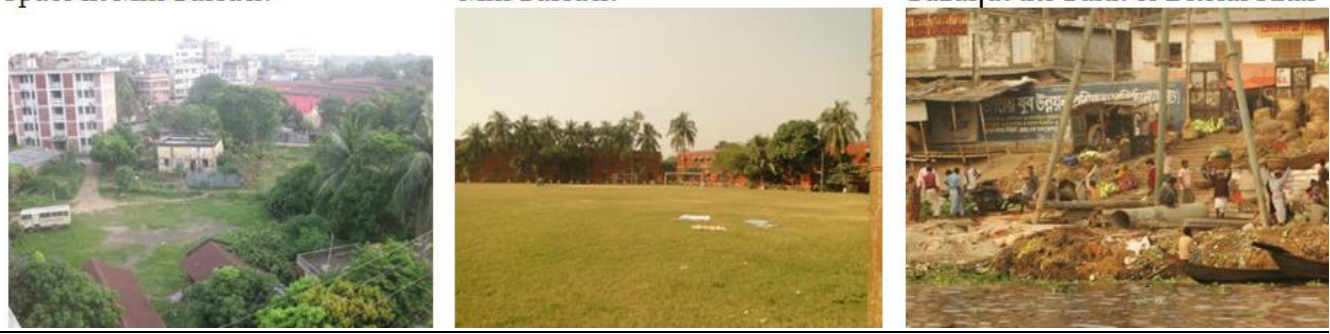

Figure 6: Community Space
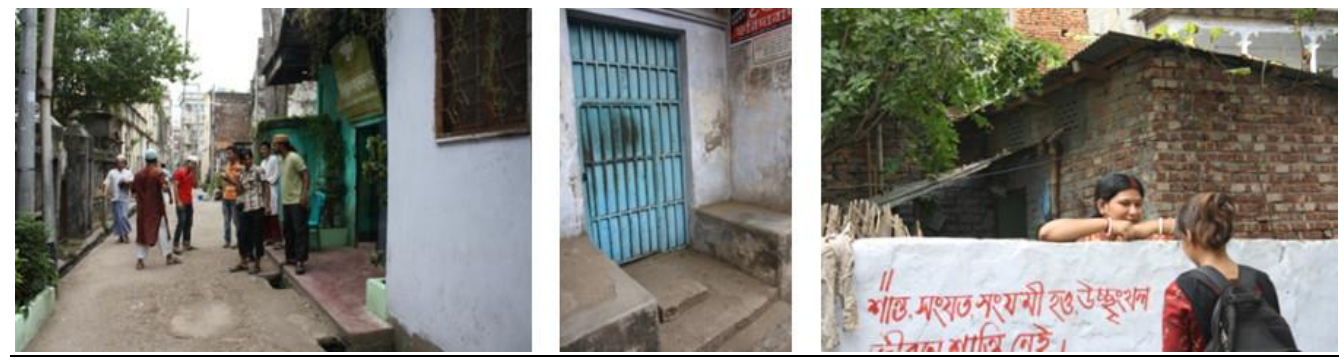

Figure 6: Areas of Intimate Contact 


\section{Building Typology}

Buildings are conceived and constructed to fulfill many socio-cultural needs for those who lived in them. And in Dhaka the architectural vocabulary of these have emerged over several periods of socioeconomic [trade, education and culture] and political development. Therefore the buildings although adopted monumentality expressive of imperialism, yet their spatial arrangements largely conformed to the patterns of traditional Bengali houses. Kalicharan Shaha Street contains the widespread character of our year old traditional houses and keeps some traces of almost all types of progression. But at present $75 \%$ of these houses are in a changed/renovated form. Nearly $90 \%$ of the total buildings of this road were residential arranged on both sides of the Kalicharan Shah road. The plots are mostly rectangular in shape with small street frontage. Average front façade width varies in between $40^{\prime}-60^{\prime}$. In few cases, the length is almost 4 to 5 times than the width (row house), with an extreme configuration of only $10^{\prime}$ width.
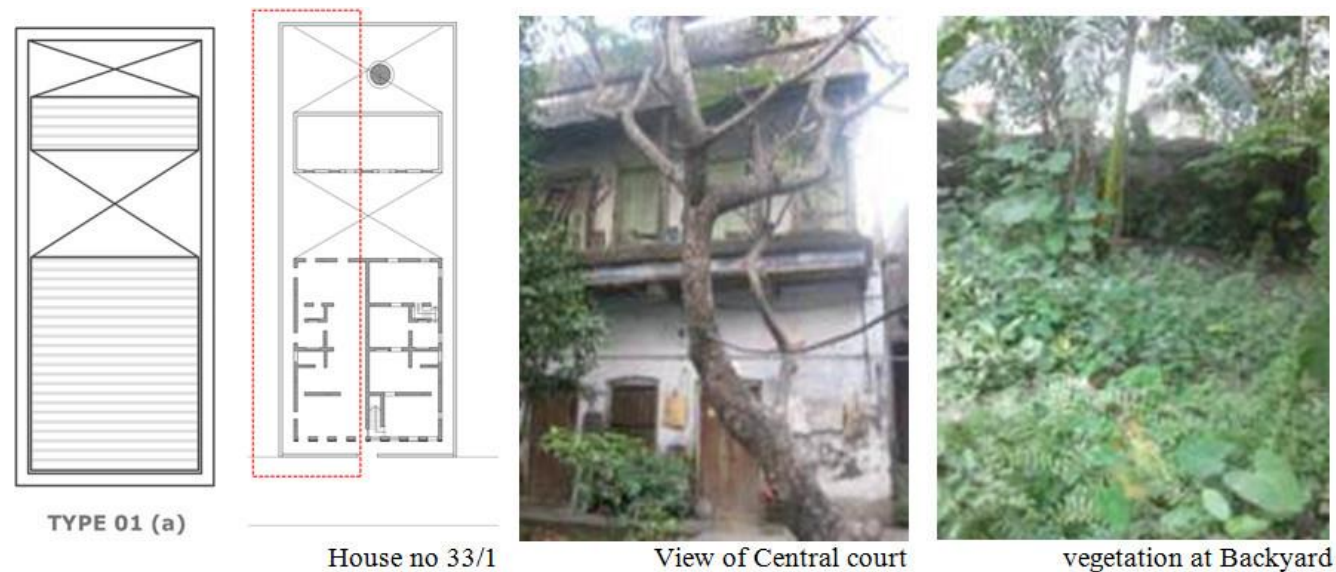

House no $33 / 1$

View of Central court

vegetation at Backyard

Figure 8: Typology 01(a): Plan and Views of Houses with Two Separate Courts [Open Central Court and Backyard]

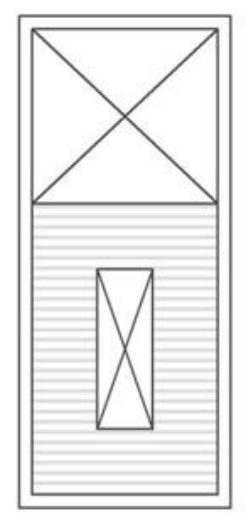

TYPE 01 (b)

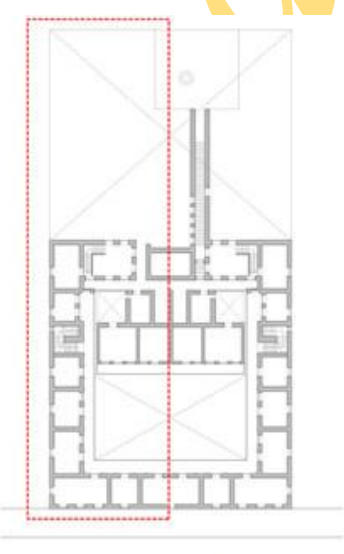

House no 10

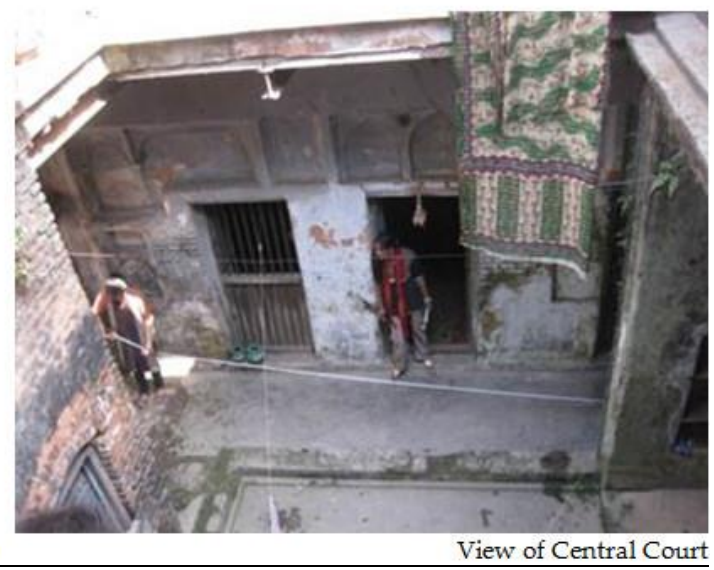

View of Central Court

Figure 9: Typology 01(b): Plan and Views of Houses with Two Separate Courts [enclosed Central Court and Backyard] 
The study has identified two types of dwellings: Courtyard and Compartment/ Row house type houses in this area which are illustrated below.

Courtyard Type: Among the total number of houses a large number comes within this category. This category of house was derived from the traditional rural house. The court is open to the sky and not enclosed, but definitely surrounded by different build forms. Four types of courtyards are found in this area.

Typology 01 [Fig 8 and fig 9] consists of two separate courts with specified serve and service area. Central court used as the open court yard for family members and the backyard for service that is used as servant's area having a well.

The central court sometimes is paved but open to the sky and used as the puja mandap, contains their private temple or Tulsi Mandir [place of Hindu worship] for the believers of Hindu community. In some cases of this type all the rooms are arranged around the narrow central court connecting with a verandah [type 01(b)][Fig 9][ House no 10]. In many cases street frontage used as commercial [shop] area i.e., public area. House No $33 / 1$ and house No 10 are examples of the houses of this type although left part of this house [red border] is in destructed form at present.

Typology 02 [Fig 10] shows three type of court i.e., public area as entry or front court, semipublic as central court and private as a backyard. Enclosed central court fulfills all the climatic considerations of cross ventilation through the individual rooms, also serves as the central circulation route. All the rooms are entered through a linked narrow verandah around the courtyard. In some case, the internal court is paved to avoid the hazard of maintenance (House 20, 20/1).

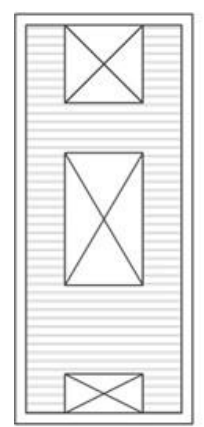

TYPE 02

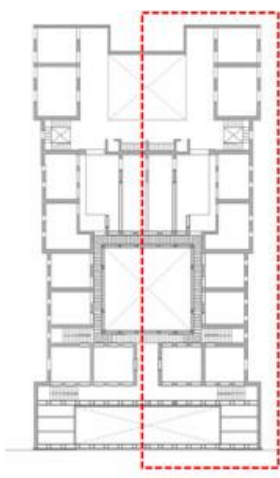

House no 20

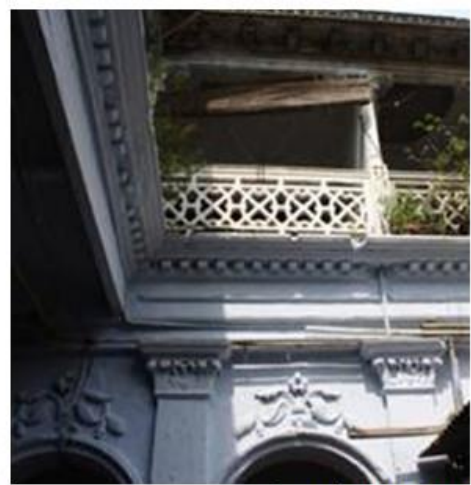

View of Front Court

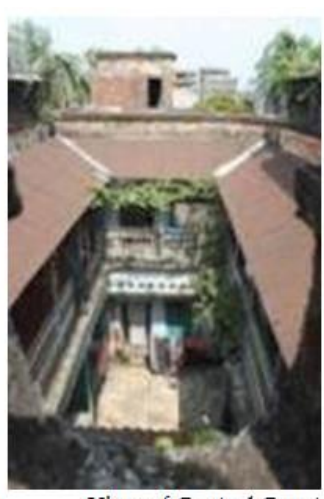

View of Central Court

Figure 10: Typology 02: Plan and Views of Houses with three Separate Courts [Front Court, enclosed Central Court and Backyard]

Typology 03 [fig 11] contains an open courtyard directly linked with the outside having segregation through a gateway and an enormous back yard for service. 


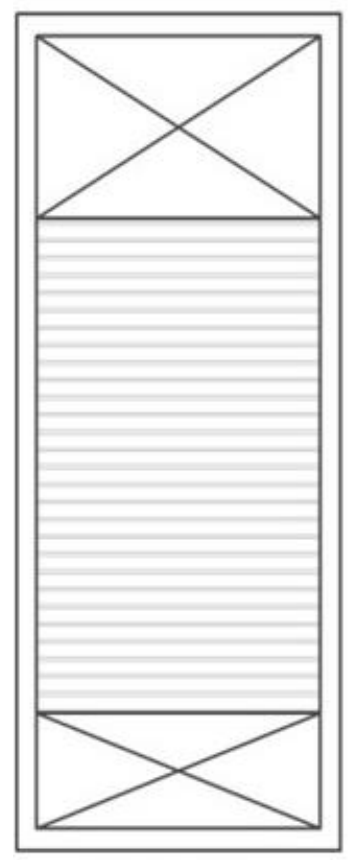

TYPE 03

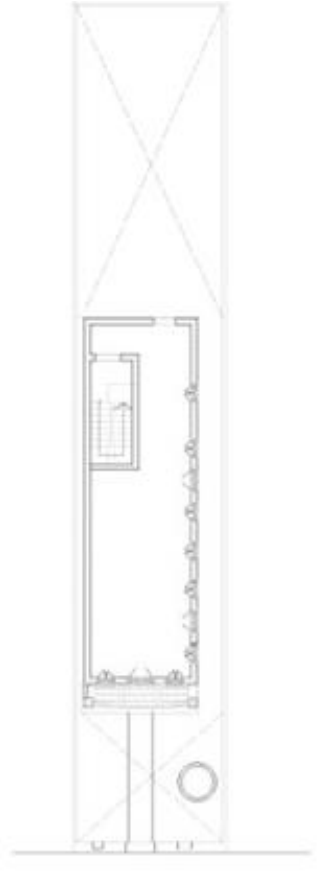

House no $10 / 5$

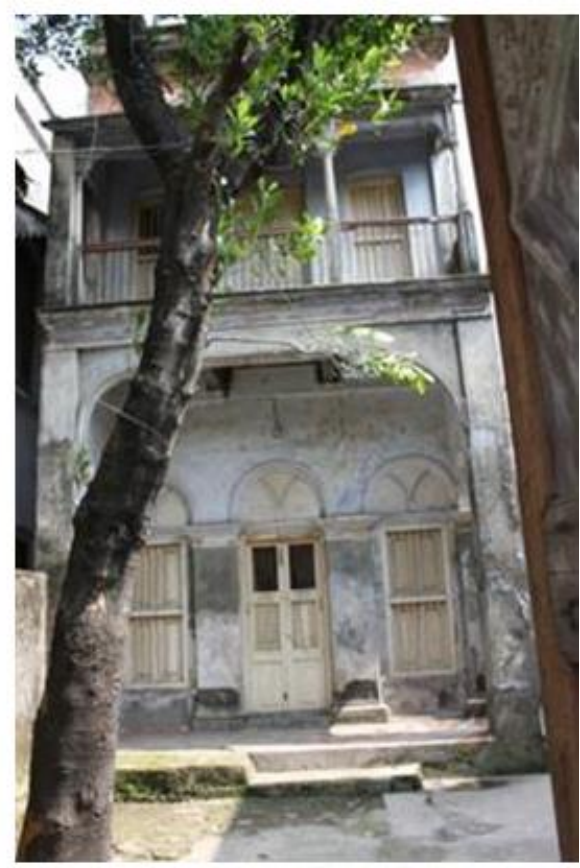

View of Front Court

Figure 11: Typology 03: Plan and Views of Houses with two Courts [Front Court and Backyard]

Typology 04 [fig 12] shows the houses with only a huge backyard for services. In the original plan, the toilet, kitchen and the bathing area were located at the back side and they did not know how to maintain this area [House no 23].

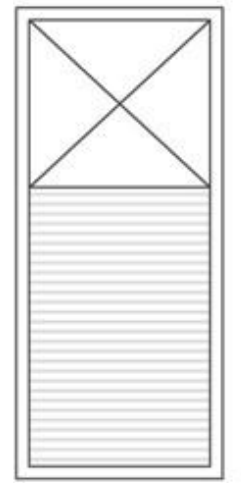

TYPE 04

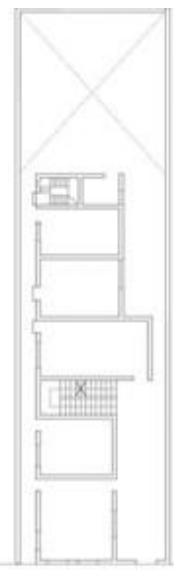

House no 23

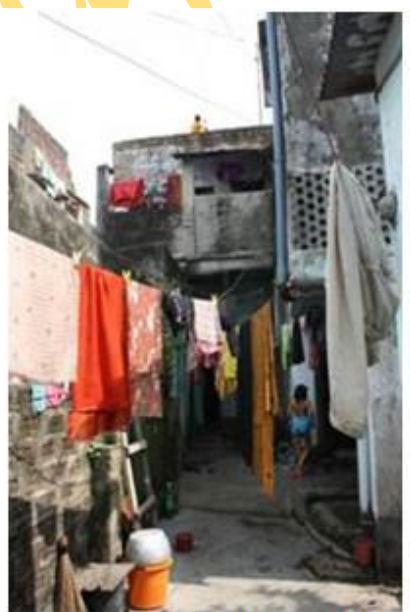

View of Circulation at Side

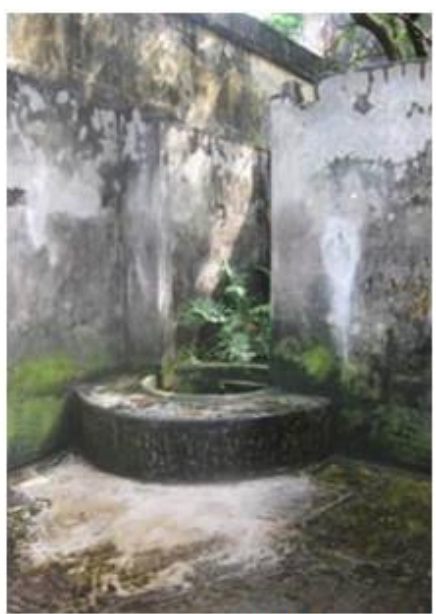

View of Backyard

Figure 12: Typology 04: Plan and Views of Houses with only Backyard as service zone 
Compartment/Row House type: These are houses with multiple compartments or rooms without any articulation of interior spaces. A narrow road of 2 - $3 \mathrm{ft}$ used to enter the house [House no 36][Fig 13]
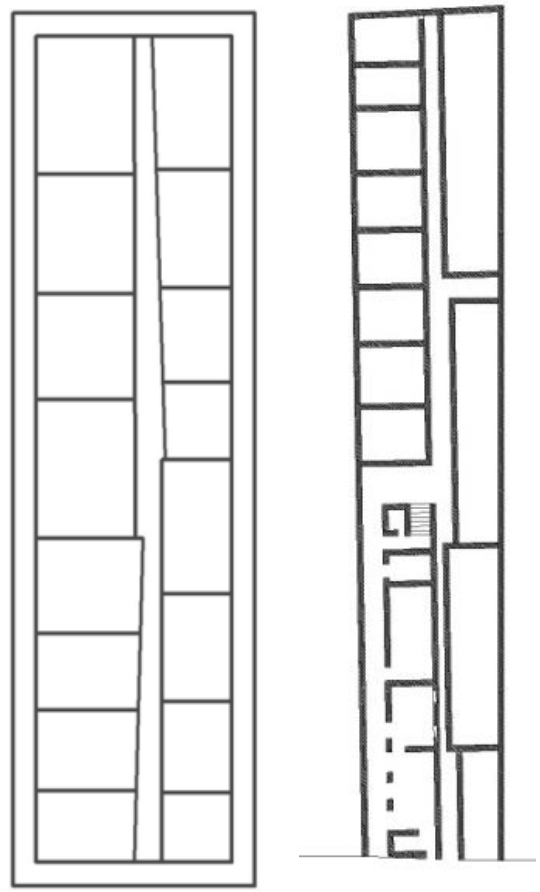

Row House

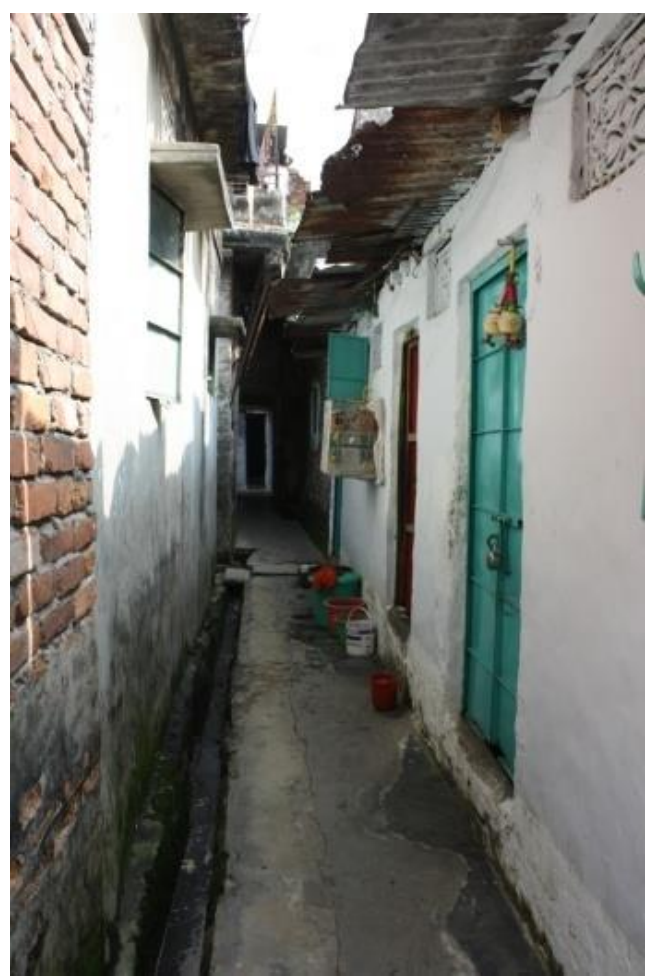

View of Circulation at Side

Figure 12: Compartment/Row House type: Plan and Views of Houses

\section{Ornamentation}

The architectural style and ornamentation Neighborhood of Kalicharan Shaha Street indicated the classical and contemporary influences along with some Mughal Legacy.

Columns: Columns as a structural element for load bearing were used since $2600 \mathrm{BC}$. In this study area, columns can be found in many amalgamated forms. The amalgamation varies between different type of styles (gothic, renaissance, classical) and also between different types (Doric, Ionic and Corinthian) [fig 13]. As being a middle or lower middleclass settlement, the dwellers adopted multiple styles of craftsmanship rather than understanding the fundamental principle of different styles. 


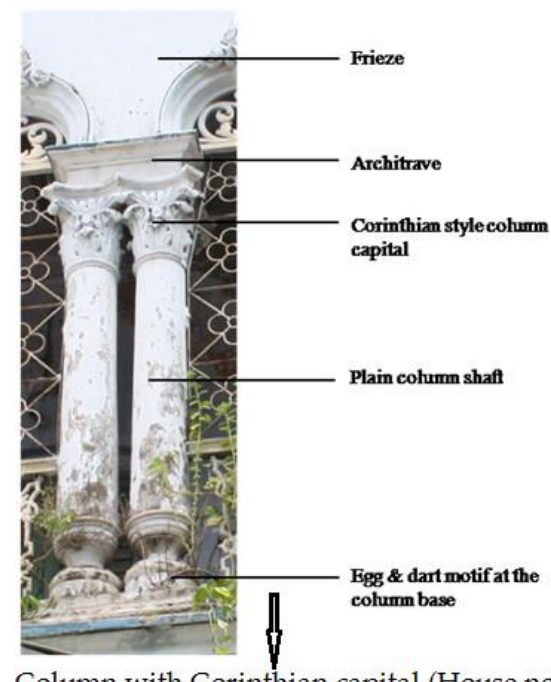

Column with Corinthian capital (House no: 10/6)

Column With amalgamation of different style (House no: 20

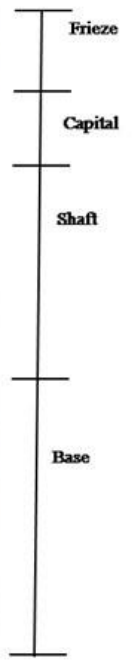

20/1)

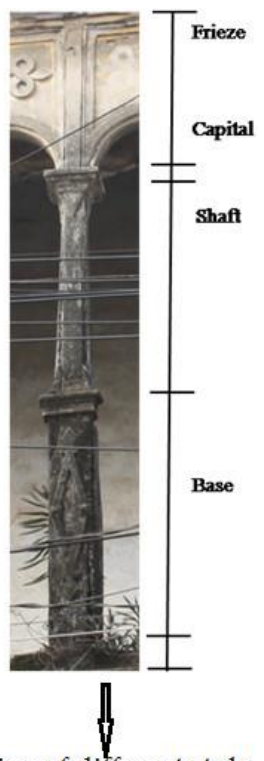

Base

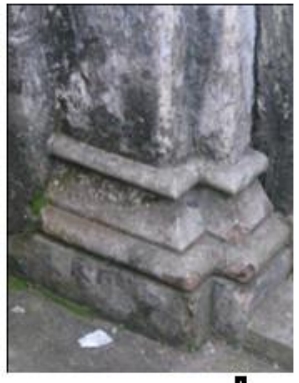

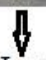

Molded base (House no: 20, 20/1)

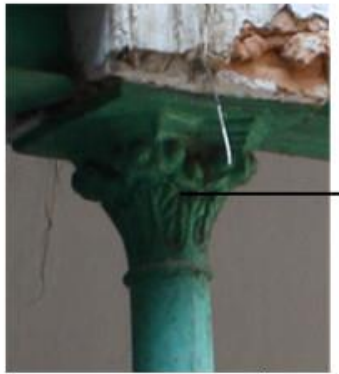

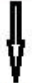

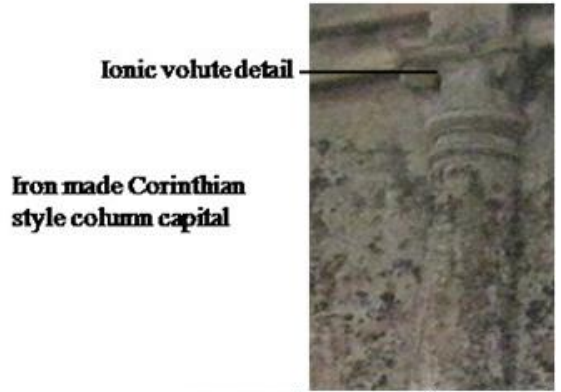

Ionic column with volutes

(House no: 10)

Column with iron corinthian capital (House no: 10/6)

Figure 13: Use of Different Types of Columns and Column Capital

Brackets: Brackets are structural elements used to support roof projections, window parapet projections, or any other projections. Brackets are usually made of wood, concrete or even metal but in the study area use of wooden brackets are popular [Fig 14].

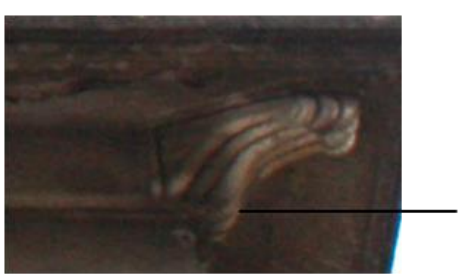

Wooden Bracket (House no: 20, 20/1)
Wooden brackets to support the roof projection

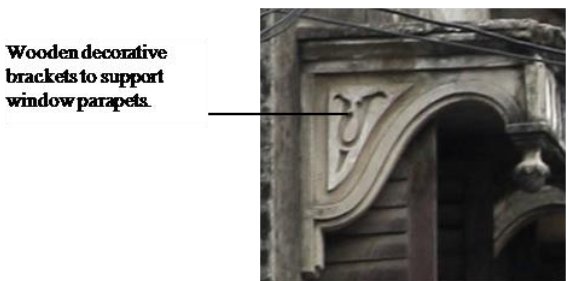

Wooden Bracket (House no: 20,20/1)

Figure 14: Use of Brackets 
Arches: Though this neighborhood didn't contain any huge mansions but some traces of the building elite group are present in this area at that respective time. Many different types of arch along with its necessary parts were signified as the symbol of colonial authority but in most cases it was a consolidation of diverse types and various elements. In most of the buildings, the original structural reasoning of arch formation were denied and arch became a decorative element replicated from elite zamindar baris rather than structural.

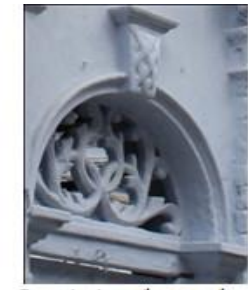

Semi circular arch with floral key stone

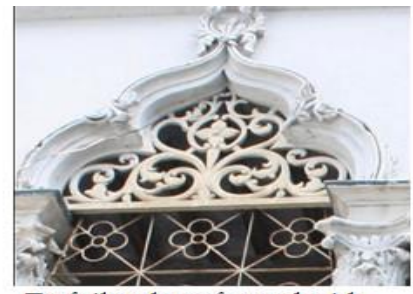

Trefoil arch perforated with floral jail (House no: 10/6)

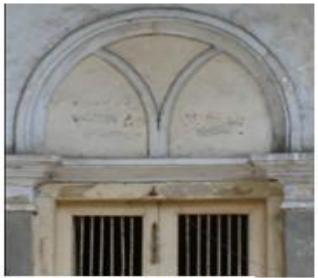

Single semi circular blind arch (House no: $10 / 5$ )

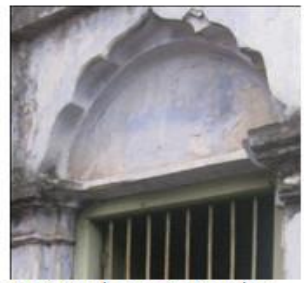

Pointed semi circular arch above blind opening

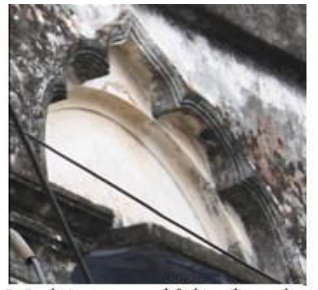

Multi cusped blind arch (House no: 33/1)

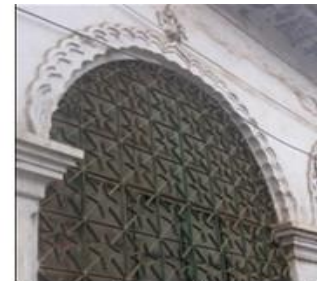

Decorative multi cusped arch

Figure 15: Use of Arches

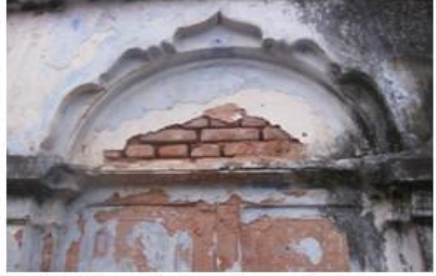

Pointed semi circular arch above blind opening

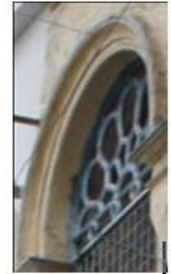

Single semi circular glazed arch

Corners: In this area, building corners are treated with mostly surface decoration rather than inserting any extra elements.

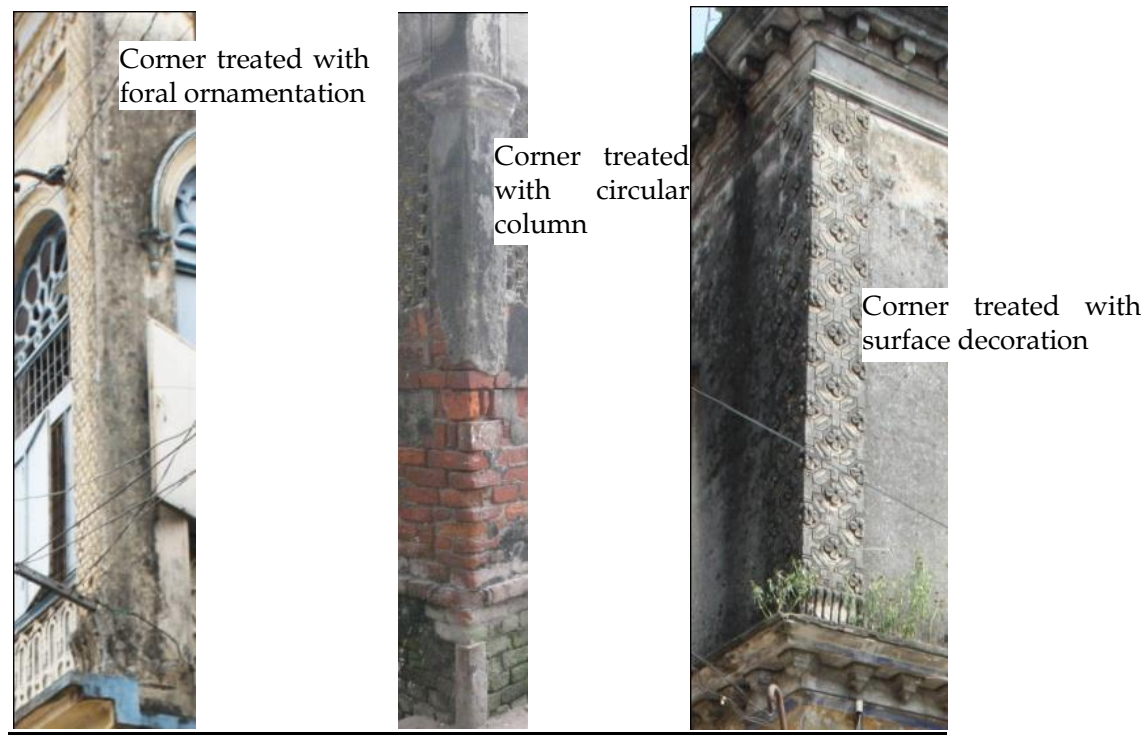

Figure 16: Corner Treatment of Buildings 
Dentil, Projections and Moldings: To hide the cornice or the projecting roof classical and renaissance architect used a decorative element named dentil. As an influence from classical period dentil became a component of ornamentation of many buildings in this area [Fig 17]. To highlight the floor levels and define floors, projections and moldings are used with decorative dentils. Projection and moldings were generally placed at plinth, floor and roof level to act as cornice (Kabir and et.al, 2009). This treatment is also present on the entry gate to emphasize its monumentality.

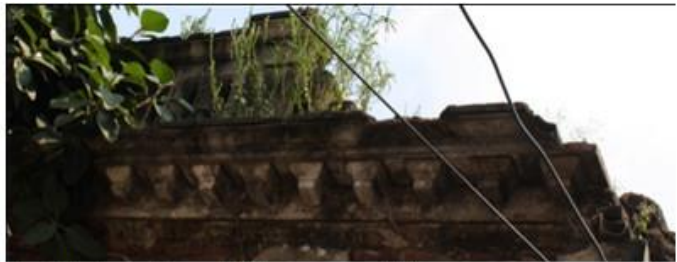

Dentil at roof level (House no: 26)

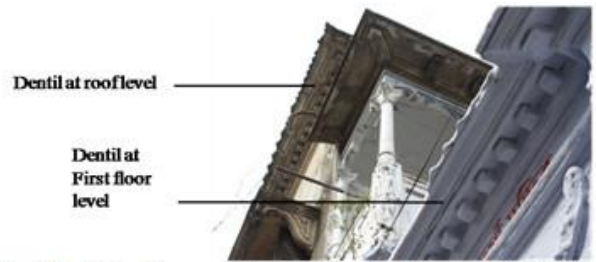

Dentil at the floor and roof level (House 20,20/1)

Figure 17: Use of Dentils

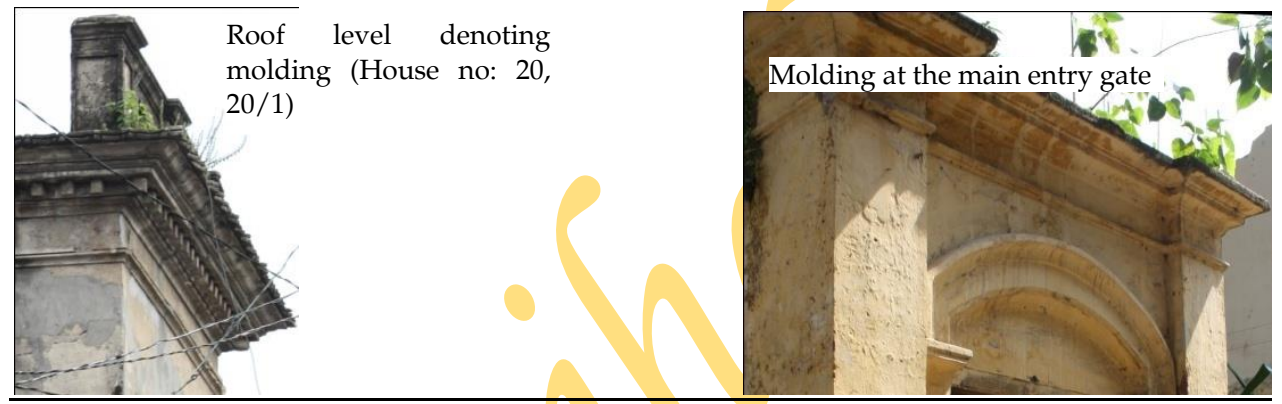

Figure 18: Use of Moldings

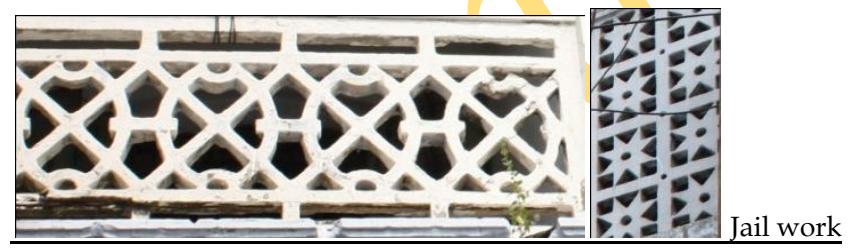

Figure 19: Use of Jalis at Elevation

Jali Work, Decorative Bands and Tablets: at Elevation: During the Mughal and Colonial period the use of jails were very popular as a sun breaker or shade in the verandah. Various types of floral pattern, as well as geometric patterns, were also used in windows, at the staircase railing, above the entry door, at the verandah drop (Kabir and et.al, 2009). As a continuation, these jail works are also present in the buildings of Kalicharan Shaha Street [Fig 19]. With the influence of renaissance period horizontal and vertical decorative bands and lines with the floral pattern were applied in many cases on the wall, corner and column, to break the monotony of the surface [Fig 20]. Tablets were depicted in various parts of buildings as plinth, top of arch, top of doorways, parapet level etc. Different types of floral and foiled tablets, tablets with historical and religious symbols also engraved on the wall [Fig 21]. 


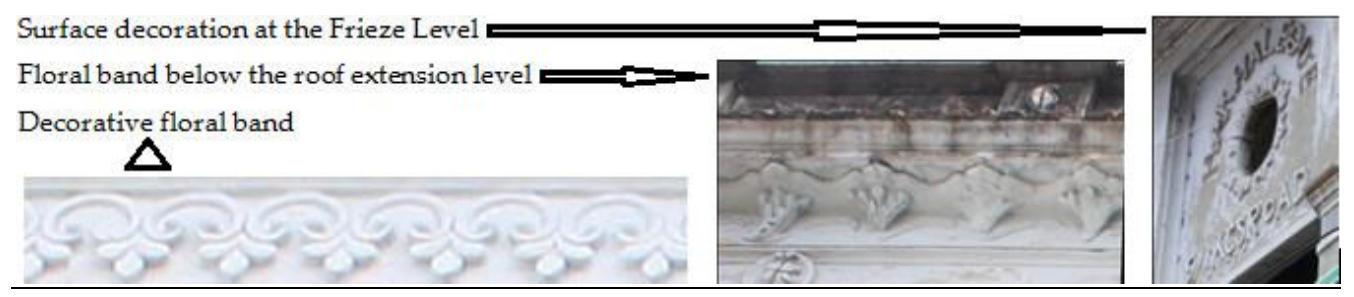

Figure 20: Use of Decorative Bands at Surface

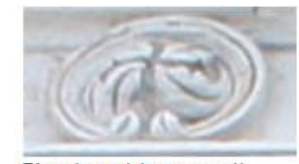

Circular tablet on wall (House no: 10/0)

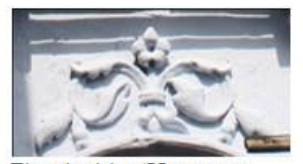

Floral tablet (House no: $20,20 / 1)$

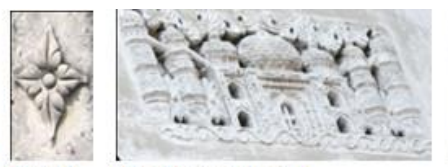

Floral tablet

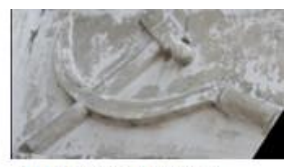

Ornamented symbol

Figure 21: Use of Tablets at Elevation

\section{Present Condition: The Heritage under Threat}

The area is currently considered as the historic core, but its original web is very difficult to maintain because of modern townscape. To meet the growing demand, the hereditary division of plots and houses and the newly built buildings around the artifacts create obstacles to the preservation historic structures. During the last 20 to 30 years a lot of demolition, alteration has been done for speculative redevelopment. The road is in a very dense condition now. The roads are so narrow that they do not permit neighbors to use cars, even they are not sufficient for an ambulance to get in. Therefore, only $2 \%$ users use cars, $10 \%$ motorcycle user and $70 \%$ inhabitant use rickshaw for their daily travels. Due to the narrowness of street and lack of footpath, walking along the road became unsafe. Besides these unplanned, spontaneous growth even obstructed the setback of houses resulting narrower roads or dead ends. At present, all the water service facilities like community water tap are located on the road and therefore, huge gathering in front of the service outlets make the road narrower [Fig22].
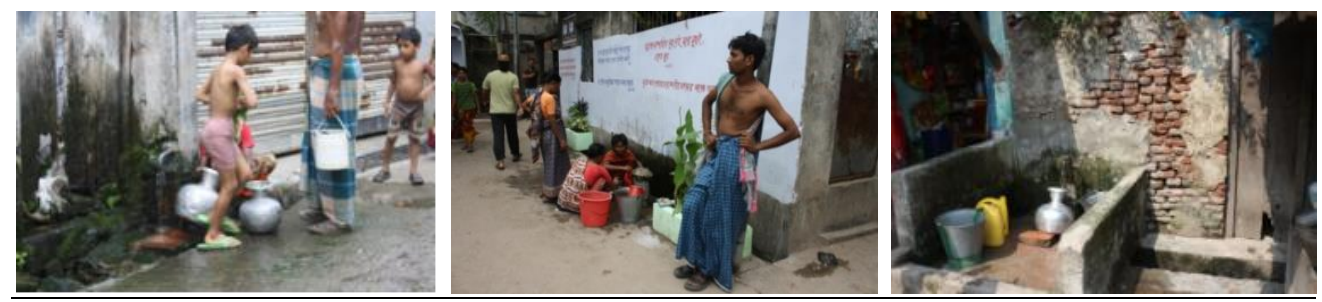

Figure 22: Services at street

Due to dense urban condition most of the open spaces are filled illegally by the slum owners. These unplanned illegal scattered developments interrupting the grain of old build forms and blocked the linkage of river Buriganga and this community. Hence, the area became very vulnerable to any natural calamity like earthquake, fire hazard, storm; the inhabitants will be in serious trouble as all the escape routes are blocked by illegal settlements. In many cases front part of the buildings are blocked by other house or rented by the owner. As a result of the land division two huge families are sharing a narrow road of 1-2 ft as their main entry [Fig 23]. 

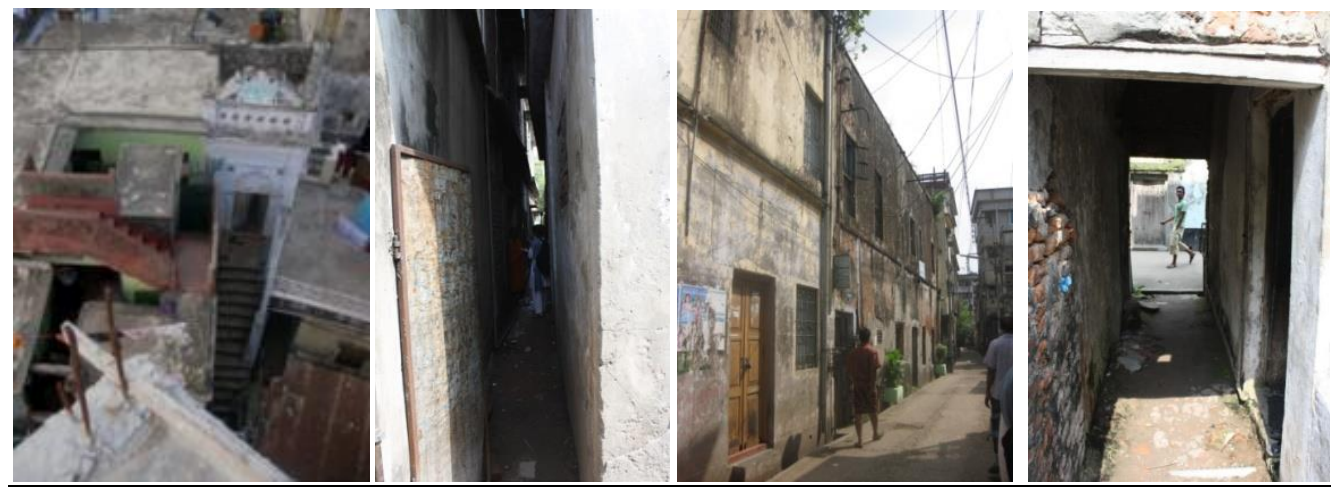

Figure 23: Interrupted Entries and Narrow Roads

Rising needs, new construction and lack of maintenance and awareness help to increase the destruction of the original fabric of the area. Old buildings are in a brittle and dilapidated condition. Most of the wall plastering, the ceiling plaster, elegant floral decoration of classical motifs on the front elevation, stair, railings and parapet - all are in the process of damage. Wild vegetation grows [Fig 24] and roots penetrate deep into the internal structures and in service yard [Fig 24]. Water penetrates through all the cracks and crevices, damp spread all over the buildings. The surface peels off with all its artistic decoration. Besides these, inappropriate repairing methods and materials unskilled labor are used, to protect damages. Many of the owners add new front façade to plaster and destroy the quality of past. Some are keeping the front façade but adding new portion at the upper level or in the courtyard [Fig 23]. These new additions or alternations of house type contribute to the deterioration and loss their originality and in most cases the original pattern of houses cannot be understood at first sight.
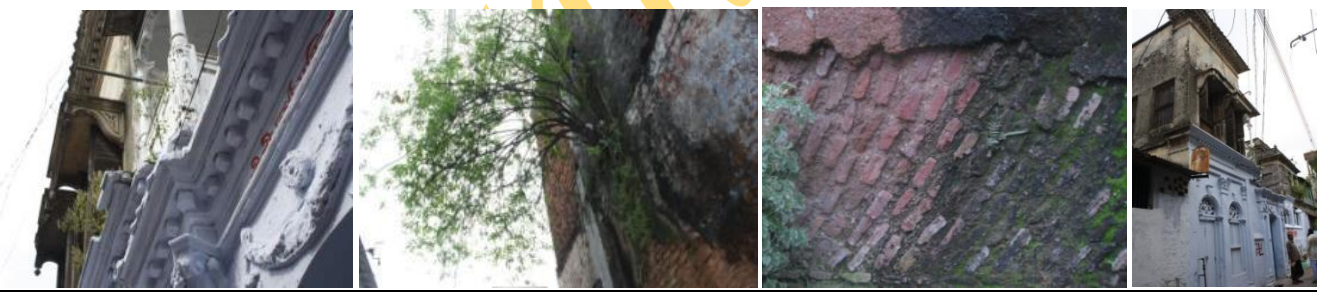

Figure 24: Growth of Vegetation, Damp and Unplanned Addition at upper level of Buildings

In the name of improvement and renovation, the owners are mostly interested in converting old buildings to high-rise apartments. The root of complex tenure pattern is one of the foremost causes for losing the inherited character of this Hindu majority settlement. Due to differences and conflicts of multiple ownership and mixed tenure, they are subjected to redevelopment or in a phase of gradual degradation. In many instances they are left abandoned and finally dismantled or developed as slum or squatter settlement [Tabassum, and et.al, 2001] or in tall buildings. It is a matter of great regret that destruction or alternations of old buildings and constructions of new one in this area is being given indiscriminately, violets a number of laws[ Bangladesh National Building Code of 1993, the Building Construction Act of 1952, the Building Construction Amendment Act of 2006 and the Building Constructions regulations of 2006 etc.] And even in most cases don't have any permission from RAJUK or City Corporation. 


\section{Conservation Issues and Prospects}

To meet the growing demand and for various reasons the heritage of Kalicharan Shaha Street are in a process of complete deterioration. These need immediate steps to save the structure from further damage. At present the government of Bangladesh is allocating money for heritage site conservation. Government also listed some heritage buildings and habitual areas for conservation. Most of our listed heritage properties are under the custodian of Directorate of Archaeology Department. Conservation of these areas is a rigorous and time consuming act. Hence, the conditions of most of listed properties are in ruined condition the expectation from the places like Kalicharan Shaha Street (which is not in the list of government heritage) is in little hope.

In spite of all these, neighborhood of Kalicharan Shaha Street, its settlement pattern, distinct architectural features are an expression of post-Mughal and British settlement, as well as an example of our past cultural property. The dynamics of this area need to be managed through the integration of historic urban elements within the existing fabric. Shifting the focus from individual buildings to the urban context during integration may reinforce the incorporation of the new structures by the urban pattern into the old framework. [Hossain, 2013] Furthermore, establishing guidelines on the nature of interventions is important to meet the standards of historic value and other design specifications for any new structures in the existing fabric. By imposing such guidelines identical new structures may ensure the authenticity and integrity of the urban structures. The street front should be considered as an important part of integration [like Shakharibazar and Taatibazar] because the continuous façade of old settlements represent a strong urban character. [Hossain, 2013]

One of the major constraints to manage the conservation of the historic area is land ownership pattern. Owners, users, and all stakeholders need to unite on a common platform to generate collective action that will protect the heritage properties. Therefore through the participatory process and empowerment of community a sense of belongingness will be developed among them, a very significant way of architectural and urban conservation. As long-term strategy, socio-economical sustainable planning for the complex conservation management and maintenance should be prepared.

The speedy growing population makes increasing demands on the world's limited resources. However, we cannot meet the expense of the resources to conserve these large numbers of buildings and sites and pay for their proper maintenance unless we find adaptive re-use functionally and economically. According to the guiding of ICOMOS [International Council on Monuments and Sites], the adoptive re-use of old buildings are often the best way to save the historic and aesthetic values of a heritage sites economically. [Tabassum, 2010] Therefore, some economically, socially and culturally feasible new uses can be incorporated with the heritage value [Tabassum, 2011] of the built environment of Kalicharan Shaha Street. Powerful control is needed to retain that quality for developing the area as pedestrian focused area and a heritage walk will be an efficient tool to revive its architectural and urban heritage.

\section{CONCLUSION}

The settlements of Kalicharan Shaha Street are an integral part of historic Old Dhaka. But the growing density of new settlements, and changes in land use or building patterns and uncontrolled urbanization have brought about rapid change to the historic fabric of this area. In spite of this the organic and intimate settlement pattern of Kalicharan Shaha Street with its architectural, aesthetic, historic, and iconic value can be a part and the buildings 
along with its people, pattern of living a part of the heritage of urban Dhaka. The site provides a unique opportunity in restoring its unique character and should have proper decisions in right time. If properly conserved and sponsored, it has every sign of becoming a renowned heritage site. So the government should take immediate action to save the heritage of Kalicharan Shaha Street.

\section{REFERENCES}

Ahmed, N., 1986, Buildings of the British Raj in Bangladesh. The University Press Limited, Dhaka, pp. 24-26, 71-76.

Akhtar, S., 1999, Bangladesher Itihas 1704-1971, Vol-3. In: Sirajul Islam (ed), Samajik Sangskririk Itihas, Asiatic society of Bangladesh, Dhaka, pp. 29-61.

Ashurst, J. and Ashurst, N., 1988, Practical Building Conservation, vol - 3: Mortars, Plasters and Renders, English Heritage Technical Handbook. Gower Technical Press, England, pp. 16.

Hossain,S.M, 2013, Strategies to integrate the Mughal Settlements in Old Dhaka, Frontiers of Architectural Research (2013)2, 420-434, available online at www.sciencedirect.co (accessed10 ${ }^{\text {th }}$ May.2015)

Immam uddin, H., 1993, Architectural Conservation Bangladesh. Asiatic Society of Bangladesh, Dhaka, pp. 2-17. Immam uddin, H., 1993, Architectural Conservation Bangladesh. Asiatic Society of Bangladesh, Dhaka, pp. 2-17.

Islam, S, 2011, Dhaka Through 400 Years, Journal of Itihas Academy, Itihas Academy Dhaka, vol 1(1), pp. 33-38

Islam, S., 2003, Banglapedia-National Encyclopedia of Bangladesh. Banglapedia Trust, Asiatic Society Bangladesh, Dhaka. http:/ / www.banglapedia.org/httpdocs/HT/Z_0009.HTM (accessed 14 ${ }^{\text {th }}$ Aug. 2010)

Kabir, N., Reza. M, and Pau, A.B, 2009, Ornamentation of Zamindar palaces of Bangladesh: An Overview, Pratnatattva, Journal of the Department of Archaeology, Department of Archaeology, Jahangirnagar University, Vol 15,Savar, Dhaka. pp. 49-77

Karim, A., 1964, Dacca: The Mughal Capital, Asiatic Society of Pakistan, Dacca, Pakistan.

Mamoon.M, 1993, Dhaka: Smrity Bismrityr Nagari, Vol1,Bangla bazar, Dhaka pp. 206-207

Morris, W., 1877, Manifesto for the Protection of Ancient Building. Society for the Protection of the Ancient Buildings (SPAB), London, pp 152.

Mowla, Q.A., 1997, Settlement Texture: Study of a Mohalla in Dhaka. Journal of Urban Design, Vol.2(2), pp: 264-265

Mowla, Q.A., 1999, Spatial Manifestation of Social Norms-the case of Urban Design in Bangladesh. Khulna University Studies, Vol.1(2), pp: 177-186

Mowla, Q.A., 2003, Urbanization and the Morphology of Dhaka-A Historical Perspective. Journal of the Asiatic Society of Bangladesh. Vol.48(1), June, pp: 145-170

Rahman, M., 2009, Old but New:: New But Old Architectural Heritage Conservation .UNESCO, Dhaka.

Rahman, S. and Mamun, M., 1993, Architectural Conservation in Practise. In: A.H. Imamuddin (ed) Architectural Conservation Bangladesh. Asiatic society Bangladesh, Dhaka, pp. 41-66.

Roshan K., M. (2014). Representation of History in Chimamanda Ngozi Adichie's Half of a Yellow Sun (2006). Asian Journal Of Humanity, Art And Literature, 1(3), 150-154.

Shaikh, Z.U. And Mowla, Q.A., 2009, Documenting the Architectural Style of the Antiquity Building in Panam Street, Pratnatattva, Journal of the Department of Archaeology, Department of archaeology, Jahangirnagar University, Vol 15,Savar, Dhaka.pp. 79-97

Tabassum, S., \& Sharmin, F. (2013). Accessibility Analysis of Parks at Urban Neighborhood: The Case of Dhaka.Asian Journal Of Applied Science And Engineering, 2(2), 48-61.

Tabassum, S., Ahmed, S., \& Romeo, T. (2014). An Investigation on Fire Safety of Air-conditioned Shopping Centers at Dhaka City. Asian Journal Of Applied Science And Engineering, 3(1), 76-88.

Tabassum,S., Afrin,S. 2010, Murapara Palace:An Expression of British Feudal Lords, Its Conservation Issues and Prospects, Published in the Proceeding of Digital Heritage Conference: Euro-med 2010 (ISSN: 1995-5332), Limassol, Cyprus, November 8th - 13th, 2010.

Tabassum,T., Sharmin,S. 2011, The Heritage of Tantibazar: Approaching for Area Conservation Journal of Itihas Academy, Itihas Academy Dhaka, vol 1(1), pp. 143-155

Tabassum,T., Sharmin,S. 2011, The Heritage of Tantibazar: Approaching for Area Conservation Journal of Itihas Academy, Itihas Academy Dhaka, vol 1(1), pp. 143-155 